\title{
PAMONG PRAJA
}

\author{
Dadang Sufianto \\ dadang.sufi54@gmail.com
}

\section{Dosen Magister Ilmu Pemerintahan Universitas Jenderal Achmad Yani}

\begin{abstract}
Abstrak
Pamong praja merupakan aparatur pemerintah yang mengemban misi pemerintah pusat di daerah dalam penyelenggaraan urusan pemerintahan umum dan urusan pemerintahan lainnya berdasarkan asas dekonsentrasi. Mereka berada dalam susunan organisasi pemerintah daerah. Peranannya sangat penting antara lain sebagai perekat negara kesatuan RI di daerah. Walaupun saat ini sebutan pamong praja tidak dinyatakan secara formal dalam peraturan perundangundangan, namun hakikat kedudukan, fungsi, dan peranannya tetap ada dan dijalankan oleh para kepala daerah yang ditetapkan oleh undang-undang sebagai wakil pemerintah pusat di wilayahnya.
\end{abstract}

Kata Kunci Negara kesatuan, pamong praja, pemerintahan daerah, dekonsentrasi, dan pemerintahan umum

\section{Pendahuluan}

Pada waktu ujian sidang tesis di salah satu perguruan tinggi, saya pernah mengajukan pertanyaan sederhana yang terkait dengan tema tesisnya kepada seorang mahasiswa peserta ujian yang sehari-harinya bekerja sebagai anggota Satuan Polisi Pamong Praja. Pertanyaannya, apakah ia tahu arti pamong praja yang dilekatkan pada penamaan instansi dimana ia bekerja. Ia menjawab bahwa pamong praja adalah pejabat yang mengemong rakyat. Jawabannya disampaikan dengan lancar dan benar. Kemudian saya bertanya lagi tentang siapa yang dimaksud dengan pejabat tersebut. Mahasiswa tersebut mulai kesulitan dalam menjawabnya dan semakin tak dapat menjawab pertanyaan yang lebih jauh dari itu. Karena demikian, maka secara sepintas saya terangkan jawabannya untuk sekedar memberi bekal awal mengenai kepamong-prajaan. 
Berangkat dari pengalaman tersebut, saya merasa perlu untuk berbagi sedikit pengetahuan tentang hal ini, karena saya pernah dididik sebagai kader pamong praja (angk. 9 APDN Bandung lulus 1977) dan menjalankan tugas kepamong-prajaan di salah satu daerah dalam jabatan-jabatan antara lain mantri polisi pamong praja, camat, pembantu bupati wilayah (wedana), dan terakhir wakil bupati. Pengetahuan tentang pamong praja dipandang penting, karena merupakan bagian dari pengetahuan sejarah pemerintahan daerah di tanah air.

Banyak hal yang dapat dibahas tentang pamong praja. Namun materi dalam tulisan ini akan dibatasi berdasarkan beberapa pertanyaan pokok berikut:

1) apakah yang dimaksud dengan pamong praja;

2) bagaimanakah riwayatnya;

3) apa fungsi dan peranannya dalam penyelenggaraan pemerintahan daerah.

\section{Pengertian Pamong Praja}

Pamong praja terdiri dari dua suku kata, ,pamong" dan „praja. " Dalam Kamus Bahasa Indonesia (1996:720), pamong berarti pengasuh, pendidik, pengurus. Sedangkan praja berarti negeri, kota. Jadi secara leksikografis (perkamusan), pamong praja adalah pengurus negeri atau pengurus pemerintahan negara.

Secara etimologis (asal usul kata), Sallata (1983:3) berpendapat bahwa istilah pamong praja berasal dari bahasa Jawa. Pamong berarti orang yang „mengemong" (membina atau membimbing). Sedangkan praja berarti negara, rakyat, kawula, kediaman, kedudukan, negeri, atau daerah. Jadi, pamong praja berarti pembina dan pembimbing rakyat di suatu negara/daerah.

Secara terminologis (peristilahan), terdapat arti pamong praja menurut beberapa ahli, yaitu: 
1) pamong praja adalah gubernur, residen, bupati, patih, walikota, wedana, dan asisten wedana, yang ditugaskan sebagai wakil pemerintah pusat di suatu daerah pemerintahan, sebagaimana dimuat dalam penjelasan UU No.6/1959 tentang Penyerahan Tugas-Tugas Pemerintah Pusat Dalam Bidang Pemerintahan Umum, Perbantuan Pegawai Negeri Dan Penyerahan Keuangannya Kepada Pemerintah Daerah (Djenal Hoesen Koesoemahatmadja, 1978: 2).

2) pamong praja adalah pejabat pemerintah pusat yang ada di daerah yang melaksanakan urusan pemerintahan umum. Dalam arti sempit, pejabat tersebut adalah kepala wilayah, sedangkan dalam arti luas termasuk dengan stafnya (Bayu Suryaningrat, 1980: 7);

3) pamong praja adalah badan pemerintah yang terdiri dari camat, wedana, patih, bupati, residen, dan gubernur (Mulia, dalam Sallata, 1983: 3);

4) pamong praja adalah perangkat atau pejabat pemerintah yang ada di daerah yang tugasnya melaksanakan urusan pemerintahan umum/ pemerintahan pusat (Soleh dan Trisantono, 2001: 20);

Setelah mencoba memahami pengertian leksikografis, etimologis, dan terminologis tentang pamong praja tersebut, penulis berkesimpulan bahwa yang dimaksud dengan pamong praja adalah aparatur pemerintah sebagai perangkat pemerintahan pusat yang berada dalam struktur pemerintahan daerah yang berfungsi menyelenggarakan urusan pemerintahan umum dan urusan pemerintahan lainnya berdasarkan asas dekonsentrasi.

Yang dimaksud dengan aparatur pemerintah dalam pengertian pamong praja tersebut adalah aparatur pemerintah yang berstatus pegawai negeri atau bukan. Jumlahnya seorang atau beberapa orang (berikut stafnya) dalam setiap tingkatan pemerintahan di daerah. Mereka berasal dari pusat atau dari daerah yang diposisikan dalam susunan organisasi pemerintah daerah sebagai Kepala Wilayah atau Kepala Daerah yang ditetapkan oleh peraturan perundangundangan sebagai wakil pemerintah pusat, dan kadang-kadang beserta stafnya. 
Mereka berfungsi menyelenggarakan urusan pemerintahan pusat berupa urusan pemerintahan umum dan urusan lain berdasarkan asas dekonsentrasi yang tidak ditugaskan kepada aparatur pemerintah di luar organisasi pemerintah daerah (instansi-instansi vertikal).

\section{Riwayat Pamong Praja}

Pada masa penjajahan Belanda sebelum tahun 1903, penyelenggaraan pemerintahan di Indonesia (Hindia Belanda) dilakukan secara sentralistik. Pemerintahan dikendalikan sepenuhnya oleh gubernur jendral yang berkedudukan di Batavia (Jakarta). Setelah dikeluarkan decentralitatie wet 1903, penyelenggaraan pemerintahan dilakukan dengan cara kombinasi sentralisasi-desentralisasi, walaupun kadar desentralisasinya masih sangat sedikit.

Dalam rangka membina, mengawasi, dan mengendalikan pemerintahan yang terselenggara di daerah, pemerintah Hindia Belanda membentuk korps pegawai Binenlands Bestuur (BB) atau „korps pegawai pemerintahan dalam negeri. ${ }^{e}$ Korps ini berada di dua jalur vertikal, yaitu:

1) Europeese $B B$ (BB Eropa) yang diisi oleh orang-orang Belanda; dan

2) Inlandse $B B$ (BB Pribumi) yang diisi oleh orang-orang pribumi bangsa Indonesia dan dikenal sebagai pangreh praja.

Mereka berstatus pegawai negeri pusat yang ditugaskan untuk mengemban misi pemerintahan pusat di daerah-daerah. Jabatan-jabatan strategis terutama kepala daerah (gouveneur, resident, assistant resident, controleur, dan adspirant controleur), diisi oleh orang Belanda. Sedangkan jabatan-jabatan bupati (regent, setingkat dengan assistant resident), wedana( districthoofd, setingkat dengan controleur), dan camat (onderdistricthoofd, setingkat dengan adspirant controleur) diisi oleh orang pribumi. BB Eropa sekaligus merupakan perangkat pengawas terhadap BB Pribumi (pangreh praja). 
Pada perang Pasifik 1941, Jepang menyerbu wilayah Hindia Belanda dan pada tgl. 9 Maret 1942 Belanda menyerah sehingga penjajahan diteruskan oleh Jepang. Pada masa penjajahan Jepang (4 tahun), korps pangreh praja tetap ada. Bedanya, kalau pada masa penjajahan Belanda terdapat dua jalur (BB Eropa dan BB Pribumi), sedangkan pada masa penjajahan Jepang hanya satu jalur, tapi ada dua tahap. Dari tahap syuи coo (residen) ke atas diisi orang-orang Jepang, sedangkan tahap ke bawahnya yaitu ken coo (bupati), gun coo (wedana, dan son coo (camat) diisi oleh orang-orang pribumi.

Setelah Indonesia merdeka, sebutan pangreh praja diganti dengan pamong praja. Menurut Bayu Suryaningrat (1980: 24), penggantian nama tersebut didasari pertimbangan psikologis dan politis. Istilah pangreh praja berkonotasi „penguasa" (ngereh=menguasai) dan dirasakan bertentangan dengan suasana demokrasi yang sedang tumbuh dan berkembang di tanah air pada waktu itu.

Dalam sejarah pemerintahan daerah, terutama setelah adanya prinsip pemberian otonomi yang seluas-luasnya menurut UU No. 22 tahun 1948 tentang Penetapan Aturan-Aturan Pokok Mengenai Pemerintahan Sendiri Di Daerah-Daerah Yang Berhak Mengatur Dan Mengurus Rumah Tangganya Sendiri; telah ada upaya penghapusan pamong praja.

Pada periode pertama, dilakukan penghapusan "kewenangan" jabatan kepamong-prajaan tertentu, dalam hal ini "kewenangan residen sebagai kepala daerah." Sebelumnya, residen adalah kepala daerah di daerah keresidenan (pemerintah setingkat di bawah provinsi). Kewenangan yang dihapus antara lain kewenangan „pengaturan“ yang dialihkan ke tingkat provinsi berdasarkan Peraturan Pemerintah no. 38 tahun 1950 tanggal 14 Agustus 1950 tentang Pemindahan Kekuasaan Residen kepada Dewan Pemerintah Daerah (DPD) Provinsi atau Gubernur Kepala Daerah Provinsi. Kewenangan lainnya, seperti koordinasi instansi vertikal di daerah, masih tetap diberikan. Hal ini terlihat dari pengaturan dalam PP No. 27 tahun 1956 tentang Penyusunan Koordinasi 
Pemerintahan Sipil. Dalam PP itu ditegaskan bahwa koordinasi instansiinstansi vertikal (organ kementerian di daerah) dipimpin oleh pamong praja. Yang dimaksud dengan pamong praja dalam peraturan tersebut adalah gubernur, residen, bupati/walikotapraja, wedana, dan camat yang ditugaskan sebagai wakil pemerintah pusat di dalam struktur pemerintahan daerah.

Pada periode kedua, dilakukan penghapusan "beberapa jenis jabatannya," dalam hal ini penghapusan "jabatan residen dan wedana," melalui berbagai peraturan tentang susunan organisasi perangkat daerah berdasarkan UU No.18 tahun 1965 tentang Pokok-Pokok Pemerintah Daerah. Sedangkan jabatan lainnya seperti gubernur, bupati, walikotamadya, dan camat tetap diadakan.

Walaupun jabatan residen dan wedana dihapus, namun sampai tahun 2000, pekerjaannya dijalankan oleh "Pembantu Gubernur Wilayah" dan "Pembantu Bupati Wilayah.” Tugasnya, mengkoordinasikan, membina, dan mengawasi pejabat kecamatan yang ada di wilayah kerjanya. Keadaan ini dialami langsung oleh penulis sendiri yang pada masa itu ditunjuk sebagai Pembantu Bupati Wilayah III Pacet tahun 1995 dan Pembantu Bupati Wilayah VI Sukajadi tahun 2000 di kabupaten Cianjur-Jabar. Pakaian seragam, tanda jabatan, tunjangan jabatan, termasuk dana dekonsentrasi, dan mobil dinas diberikan oleh pemerintah pusat dan pemerintah daerah. Baru pada tahun 2000, dengan kebijakan baru mengenai susunan organisasi pemerintahan daerah yang didasarkan pada UU No. 22 tahun 1999, pemda kabupaten Cianjur dan pemdapemda kabupaten/kota lainnya menghapus sama sekali jabatan tersebut. Penghapusan ini dilakukan karena jabatan tersebut tidak ada dalam susunan organisasi yang diatur dalam PP No. 84 tahun 2000 tentang Pedoman Organisasi Perangkat Daerah yang kemudian dicabut dan diganti dengan PP No. 8 tahun 2003 tentang Pedoman Organisasi Perangkat Daerah.

Pada periode ketiga, dilakukan penghapusan status kepegawaiannya, dalam hal ini penghapusan statusnya sebagai pegawai pusat yang instansi 
induknya kementerian dalam negeri. Dulu (sampai tahun 2000-an) di dalam pemerintahan daerah masih ada pegawai kementerian dalam negeri yang berstatus „dpk (dipekerjakan) atau „dpb (diperbantukan). Penulis sendiri pada awalnya adalah pegawai negeri sipil departemen dalam negeri (NIP 010081xxx) yang berstatus „dpb di kabupaten Cianjur-Jabar. Sekarang

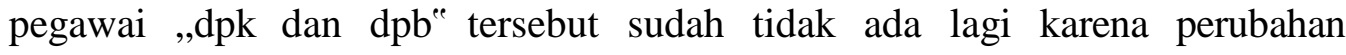
peraturan perundang-undangan mengenai kepegawaian negara. Pegawaipegawai tersebut dialihkan statusnya menjadi pegawai negeri daerah.

Terhadap upaya penghapusan pamong praja tersebut ada dua golongan sikap, yaitu golongan yang setuju dan tidak setuju. Pihak yang setuju berpendapat bahwa keberadaan korps ini selain dianggap sebagai peninggalan kolonial dan tidak efisien dari segi penggunaan keuangan negara, juga terasa menimbulkan dualisme kepemimpinan pemerintahan daerah (pada awalnya, dianggap menyaingi Dewan Pemerintah Daerah) yang tidak sesuai dengan semangat desentralisasi pada saat itu (prinsip pemberian otonomi yang seluasluasnya). Sedangkan pihak yang tidak setuju berpendapat bahwa korps ini merupakan "unsur perekat negara kesatuan RI di daerah" yang telah ada sebelum bangsa Indonesia merdeka dan mereka telah turut berjuang menegakkan kemerdekaan. Keberadaannya diperlukan untuk mencegah aktivitas desentralistik yang berlebihan. Pemberian otonomi yang luas atau seluas-luasnya tidak berarti semua kewenangan pemerintahan diserahkan kepada daerah. Kalau itu terjadi, maka negara kesatuan akan hilang maknanya. Seluas apapun otonomi daerah, harus masih tetap ada urusan pemerintahan yang ditangani pemerintah pusat dalam penyelenggaraan pemerintah daerah yang dilakukan oleh aparaturnya. Dengan cara begitu, ikatan dalam negara kesatuan dapat terjaga/terpelihara sampai jenjang pemerintahan yang paling bawah.

Walaupun telah ada upaya penghapusan korps pamong praja secara total, eksistensi pamong praja tetap tidak berubah. Upaya penghapusan tersebut 
hanya berhasil dalam bentuk pengurangan jenis jabatan dan perubahan status kepegawaiannya.

\section{Fungsi dan Peran Pamong Praja dalam Penyelenggaraan Urusan Pemerintahan Berdasarkan Asas Dekonsentrasi}

\section{Fungsi Pamong Praja dalam pelaksanaan Asas Dekonsentrasi}

Asas dekonsentrasi merupakan prinsip dasar dalam penyelenggaraan pemerintahan daerah selain desentralisasi dan tugas pembantuan. Dekonsentrasi pada hakikatnya merupakan sentralisasi juga, hanya teknis pelaksanaannya diperlunak dengan melimpahkan wewenang kepada aparatur pemerintah pusat yang ada di Daerah (daerah otonom) untuk menjalankan kebijakan pemerintah pusat yang disesuaikan dengan situasi dan kondisi daerah masing-masing berikut pegawai, prasarana, sarana, dan dananya.

Aparatur dekonsentrasi terdiri dari 2 (dua) golongan, yaitu:

1) golongan aparatur pemerintah di luar susunan organisasi pemerintahan daerah, dalam hal ini adalah para pimpinan instansi vertikal, seperti kepala kejaksaan tinggi/negeri, pangdam/dandim/danramil, dan kapolda/kapolres /kapolsek; dan

2) golongan aparatur pemerintah di dalam susunan organisasi pemerintahan daerah, dalam hal ini adalah pamong praja.

Karena fungsinya dipandang penting bagi kepentingan negara kesatuan, maka dalam berbagai peraturan perundang-undangan mengenai pemerintahan daerah, pamong praja selalu ditetapkan sebagai alat pusat yang diberi kewenangan dekonsentrasi. Walaupun perlu digaris-bawahi bahwa „sebutan pamong praja ${ }^{\text {ee }}$ tidak selalu dimunculkan. Tentang hal ini dapat kita telusuri dari isi berbagai undang-undang tentang pemerintahan daerah.

Sejak Indonesia merdeka sampai sekarang, undang-undang tentang pemerintahan daerah adalah sebagai berikut: 
1) Undang-undang No.1 tahun 1945 tentang Peraturan Mengenai Kedudukan Komite Nasional Daerah.

2) Undang-undang No. 22 Tahun 1948 tentang Penetapan Aturan-Aturan Pokok Mengenai Pemerintahan Sendiri Di Daerah-Daerah Yang Berhak Mengatur Dan Mengurus Rumah Tangganya Sendiri.

3) Undang-undang No. 1 tahun 1957 tentang Pokok-Pokok Pemerintahan Daerah yang sebagian isinya diubah dengan Penetapan Presiden No. 6 tahun 1959 tentang Pemerintah Daerah dalam hal yang khusus yaitu mengenai susunan dan kedudukan pemerintah daerahnya.

4) Undang-undang No. 18 tahun 1965 tentang Pokok-Pokok Pemerintah Daerah.

5) Undang-undang No. 5 tahun 1974 tentang Pokok-Pokok Pemerintahan Di Daerah.

6) Undang-undang No.22 tahun 1999 tentang Pemerintahan Daerah.

7) Undang-undang No. 32 tahun 2004 tentang Pemerintahan Daerah sebagaimana telah diubah terakhir dengan UU No. 12 tahun 2008 tentang Perubahan Kedua atas Undang-Undang No. 32 tahun 2004 tentang Pemerintahan Daerah.

8) Undang-undang No. 23 tahun 2014 tentang Pemerintahan Daerah yang (sebagian pasalnya) diubah dengan Perpu No. 2 tahun 2014 yang ditetapkan menjadi undang-undang dengan UU No. 2 tahun 2015, dan kemudian diubah kembali dengan UU No. 9 tahun 2015.

Pada masa pemberlakuan UU No.1 tahun 1945, yang ditetapkan sebagai kepala daerah adalah residen, walikota dan bupati yang menjadi ketua bukan anggota BPRD (badan perwakilan rakyat daerah) merangkap sebagai ketua BE (badan eksekutif merangkap anggota). Mereka tidak dipilih rakyat tetapi ditunjuk/diangkat pemerintah pusat untuk menjalankan tugas desentralisasi (sebagai alat daerah) dan dekonsentrasi (sebagai alat pusat). 
Pada masa pemberlakuan UU No. 22 tahun 1948, provinsi diadakan kembali, sedangkan keresidenan dan kewedanaan dihapus. Karena itu yang ditetapkan sebagai kepala daerah adalah gubernur, bupati, dan walikotapraja. Dalam peraturan pelaksanaannya, para kepala daerah tersebut masih disebut sebagai pamong praja, dan karenanya ia menjalankan tugas desentralisasi (sebagai alat daerah) dan dekonsentrasi (sebagai alat pusat).

Pada masa pemberlakuan UU No. 1 tahun 1957, dengan Penpres No. 6 tahun 1959 ditetapkan bahwa kepala daerah (gubernur, bupati/walikotapraja) diangkat sebagai pejabat negara oleh pemerintah pusat dari calon yang diajukan DPRD atau di luar itu dan menjalankan kewenangan dekonsentrasi (sebagai alat pusat) dan kewenangan desentralisasi (sebagai alat daerah).

Pada masa pemberlakuan UU No. 18 tahun 1965, kepala daerah (gubernur, bupati/walikotapraja) juga menjalankan kewenangan dekonsentrasi (sebagai alat pusat) dan kewenangan desentralisasi (sebagai alat daerah).

Pada masa pemberlakuan UU No.5 tahun 1974, terdapat dua golongan kepala pemerintahan, yaitu kepala daerah (tingkat I dan tingkat II), dan kepala wilayah (gubernur sebagai kepala wilayah provinsi, bupati/walikotamadya sebagai kepala wilayah kabupaten/kotamadya, walikota sebagai kepala wilayah kota administratif, dan camat sebagai kepala wilayah kecamatan). Gubernur kepda Tk.I dan bupati/walikotamadya kepda Tk.II menjalankan kewenangan dekonsentrasi (sebagai alat pusat) dan kewenangan desentralisasi (sebagai alat daerah). Sedangkan walikota dan camat menjalankan kewenangan dekonsentrasi (sebagai alat pusat). Dengan demikian kedudukan pamong praja pada masa pemberlakuan undang-undang ini lebih kuat dari pada masa sebelumnya, karena aparatur dekonsentrasinya ditetapkan sampai pada tingkat kecamatan seperti pada masa pemberlakuan UU No.1 tahun 1945 dan UU No. 22 tahun 1948.

Pada masa pemberlakuan UU No. 22 tahun 1999, kepala daerah provinsi disebut gubernur yang berkedudukan rangkap sebagai kepala daerah 
(desentralisasi) dan wakil administrasi (dekonsentrasi). Selaku kepala daerah, ia bertanggung-jawab kepada DPRD provinsi sedangkan sebagai alat pusat, ia bertanggungjawab kepada presiden. Di tingkat kabupaten/kota, kepala daerahnya disebut bupati/walikota yang berkedudukan sebagai alat daerah (desentralisasi) murni. Dengan demikian, kedudukan pamong praja pada masa ini hanya ada di tingkat provinsi saja (gubernur sebagai wakil administrasi).

Pada masa pemberlakuan UU No.32 tahun 2004, gubernur berkedudukan sebagai kepala daerah (desentralisasi) merangkap wakil pemerintah pusat (dekonsentrasi). Baik sebagai alat daerah dan maupun sebagai alat pusat, ia bertanggungjawab kepada presiden. Sedangkan di tingkat kabupaten/kota, bupati/walikota berkedudukan sebagai alat daerah (desentralisasi) murni. Camat merupakan perangkat daerah (desentralisasi). Dengan demikian, pamong praja pada masa inipun hanya ada di tingkat provinsi saja (gubernur sebagai wakil pemerintah pusat).

Terakhir, dengan UU No. 23 tahun 2014 yang sekarang berlaku, gubernur berkedudukan sebagai kepala daerah (desentralisasi) merangkap wakil pemerintah pusat (dekonsentrasi). Sedangkan bupati/walikota berkedudukan sebagai alat pusat dalam menjalankan pemerintahan umum (urusan ini dapat dikatakan bagian dari dekonsentrasi juga). Sedangkan camat masih berkedudukan sebagai perangkat daerah. Berarti, pamong praja pada masa sekarang hanya gubernur dan bupati/walikota.

Setelah menelusuri isi pokok semua undang-undang pemerintahan daerah tersebut sepanjang mengenai kedudukan kepala daerahnya, dapat diketahui bahwa kepala unit pemerintahan perantara (keresidenan atau provinsi), selalu diberi kewenangan dekonsentrasi. Sedangkan kepala pemerintahan unit dasar (kabupaten/kota) hanya diberi kadang-kadang, dan yang terakhir menurut undang-undang yang berlaku sekarang (UU No.23 tahun 2014), bupati/walikota mengemban misi pemerintah pusat sebagai penanggungjawab 
urusan pemerintahan umum (dapat dikatakan bagian dari urusan dekonsentrasi).

Menurut Suwandi (dalam Roesmidi, 2010: 31-32), ada dua tujuan utama mengapa pemerintah pusat menetapkan kebijakan dekonsentrasi, yaitu tujuan politis dan administrasi. Tujuan politisnya ada 3 yaitu:

1) Pemerintah pusat melalui aparaturnya dapat mengetahui dan menyerap aspirasi daerah.

2) Pemerintah pusat melalui aparaturnya dapat mengupayakan untuk memperoleh dukungan daerah terhadap kebijakannya.

3) Pemerintah pusat karena keberadaan aparaturnya di daerah, tidak mendapat tekanan langsung dari daerah jika timbul masalah akibat penolakan kebijakannya.

Sedangkan tujuan administratifnya ada 4 yaitu:

1) Pemerintah pusat melalui aparaturnya dapat menyesuaikan rencana program dan pelaksanaan pembangunan dengan kebutuhan daerah.

2) Pemerintah pusat melalui aparaturnya akan dapat mengetahui dan mengembangkan potensi daerah untuk kepentingan nasional dan daerah yang bersangkutan.

3) Pemerintah pusat melalui aparaturnya akan dapat lebih efisien dalam melaksanakan program-programnya daripada dikerjakan langsung secara keseluruhan oleh dirinya.

4) Pemerintah pusat melalui aparaturnya akan lebih dapat menjamin "speed of action" atas kebijakan atau program-programnya.

\section{Fungsi Pamong Praja dalam penyelenggaraan Urusan Pemerintahan Umum}

Seperti telah dikemukakan bahwa pamong praja adalah aparatur pemerintah yang mengemban misi pemerintah pusat dalam penyelenggaraan pemerintahan daerah. Arti pemerintahan daerah itu sendiri secara sempit adalah 
aktivitas pemerintah daerah (kepala daerah dan perangkat daerah) dalam penyelenggaraan urusan daerah dan urusan pusat. Urusan daerah adalah urusan otonomi daerah (desentralisasi), sedangkan urusan pusat adalah urusan medebewind, dekonsentrasi, dan pemerintahan umum.

Khusus mengenai desentralisasi, medebewind, dekonsentrasi, dan pemerintahan umum perlu diperjelas lagi karena ada perbedaan pada pelakunya. Pelaku desentralisasi dan medebewind adalah Daerah (daerah otonom, ada pelibatan DPRD), sedangkan pelaku dekonsentrasi dan pemerintahan umum adalah pejabatnya (bukan Daerah, tanpa pelibatan DPRD). Dengan demikian pengemban misi pemerintah pusat yang murni di lingkungan pemerintahan daerah adalah pamong praja sebagai aparatur

\section{dekonsentrasi dan pemerintahan umum.}

Pada masa perundang-undangan dahulu, bobot pelaksanaan asas dekonsentrasi diletakkan pada penyelenggaraan urusan pemerintahan umum. Berbeda halnya dengan keadaan sekarang, karena variasi urusan dekonsentrasi bertambah, maka urusan pemerintahan umum dipisahkan tersendiri. Berdasarkan UU No. 23 tahun 2014, sebagian urusan konkuren (urusan bersama pusat-daerah yang dibagi berdasarkan skalanya) yang menjadi bagian pemerintahan pusatpun, dapat dijadikan bagian dari tugas dekonsentrasi bagi gubernur sebagai wakil pemerintah pusat.

Yang dimaksud dengan urusan pemerintahan umum (pada masa sekarang) adalah urusan pemerintahan setelah dikurangi urusan absolut (urusan yang mutlak diselenggarakan pemerintah pusat), desentralisasi, medebewind, dan dekonsentrasi. Menurut UU No. 23 tahun 2014 yang sekarang berlaku, yang dimaksud dengan urusan pemerintahan umum ialah urusan pemerintahan yang menjadi kewenangan presiden sebagai kepala pemerintahan.

Berdasarkan hasil analisis terhadap berbagai peraturan perundangundangan tentang pemerintahan daerah, urusan pemerintahan umum memang 
selamanya berstatus sebagai urusan pusat, walaupun rinciannyanya berubahubah.

Rincian urusan pemerintahan umum versi UU No. 5 tahun 1974 yaitu:

1) Membina ketenteraman dan ketertiban di wilayahnya sesuai dengan kebijakan ketenteraman dan ketertiban yang ditetapkan oleh pemerintah pusat.

2) Melaksanakan segala usaha dan kegiatan di bidang pembinaan ideologi negara, politik dalam negeri dan pembinaan kesatuan bangsa sesuai dengan kebijakan yang ditetapkan oleh Pemerintah Pusat.

3) Menyelenggarakan koordinasi atas kegiatan-kegiatan antar instansi pusat dan antara instansi pusat dengan instansi daerah.

4) Membimbing dan mengawasi penyelenggaraan pemerintahan daerah atau pemerintah bawahannya.

5) Mengusahakan secara terus-menerus agar semua peraturan perundangundangan dan peraturan daerah dilaksanakan oleh istansi/pejabat pusat dan daerah serta mengambil tindakan yang dianggap perlu untuk menjamin kelancaran penyelenggaraan pemerintahan.

6) Melaksanakan semua tugas pemerintahan yang dengan atau berdasarkan peraturan perundang-undangan diberikan kepadanya.

7) Melaksanakan segala tugas pemerintahan yang tidak termasuk dalam tugas instansi pemerintahan lainnya baik pusat maupun daerah.

Sedangkan rincian urusan pemerintahan versi UU No. 23 tahun 2014, yaitu:

1) pembinaan wawasan kebangsaan dan ketahanan nasional dalam rangka memantapkan pengamalan Pancasila, pelaksanaan Undang-Undang Dasar Negara Republik Indonesia Tahun 1945, pelestarian Bhinneka Tunggal Ika serta pemertahanan dan pemeliharaan keutuhan Negara Kesatuan Republik Indonesia;

2) pembinaan persatuan dan kesatuan bangsa; 
3) pembinaan kerukunan antarsuku dan intrasuku, umat beragama, ras, dan golongan lainnya guna mewujudkan stabilitas kemanan lokal, regional, dan nasional;

4) penanganan konflik sosial sesuai ketentuan peraturan perundangundangan.

5) koordinasi pelaksanaan tugas antarinstansi pemerintahan yang ada di wilayah Daerah provinsi dan Daerah kabupaten/kota untuk menyelesaikan permasalahan yang timbul dengan memperhatikan prinsip demokrasi, hak asasi manusia, pemerataan, keadilan, keistimewaan dan kekhususan, potensi serta keanekaragaman Daerah sesuai dengan ketentuan peraturan perundang-undangan;

6) pengembangan kehidupan demokrasi berdasarkan Pancasila; dan

7) pelaksanaan semua urusan pemerintahan yang bukan merupakan kewenangan Daerah dan tidak dilaksanakan oleh instansi vertikal.

Ketujuh urusan pemerintahan umum tersebut dapat dikatakan gugusan tugas untuk memperkuat ikatan di negara kesatuan RI sebagai bagian dari tanggungjawab pemerintah pusat. Di dalamnya mengandung semangat untuk memelihara/menjaga tetap tegaknya "NKRI." Itulah kebutuhan nyata dalam tatakelola pemerintahan di negara kesatuan. Kekuatan negara kesatuan dari sudut pandang ilmu pemerintahan justru terletak pada "keseimbangan sentralisasi-desentralisasi" sehingga pemerintahan pusat dan pemerintahan daerahpun sama-sama kuat.

Dari kedua rumusan urusan pemerintahan umum tersebut, yang hampir tak pernah berubah adalah tugas yang ke-7 yang dalam ilmu pemerintahan lazim dikatakan tugas tampungtantra atau vrij bestuur. Tugas ini menunjukkan prinsip "tidak ada satu pekerjaanpun dalam melayani masyarakat yang boleh diabaikan pemerintah." Tugas ini mencerminkan cara pemerintah pusat dalam mengurus kepentingan masyarakat di seluruh wilayah/daerah jika menghadapi suatu pekerjaan yang tidak ada instansi yang membidanginya atau yang 
mengerjakannya. Dalam pelaksanaan tugas inilah pamong praja banyak berperan. Jenis pekerjaan dalam pelaksanaan tugas ini sangat sulit diinventarisasi sebelumnya, karena keberadaannya muncul sewaktu-waktu dan karena itu pulalah membutuhkan kemampuan aparaturnya untuk berimprovisasi. Asumsinya, dengan jenis tugas tampungtantra ini, tugas-tugas pemerintahan telah terbagi habis.

\section{Peranan Pamong Praja dalam Pembangunan, Kemasyarakatan, Pemerintahan, dan Ketatanegaraan}

Dalam pidatonya di depan Kongres Serikat Pekerja Kementerian Dalam Negeri tanggal 3 Desember 1953 di Bogor, Bung Karno mengemukakan bahwa arti pamong praja lebih luas dari sekedar pengasuh dan pemimpin. Pamong praja adalah orang "yang mengemong rakyat," seperti orang tua yang mengemong anaknya. Prinsip kerjanya "tut wuri handayani," artinya mengikuti, memperhatikan, dan mempengaruhi dari belakang orang-orang yang dipimpinnya.

Bertolak dari penegasan Bung Karno tersebut, pamong praja dibina agar dapat berperan seperti orang tua yang mengurus anaknya. Dengan didasari rasa kasih sayang dan tanggungjawabnya, orang tua mengasuh anaknya dalam beraktivitas. Mengasuh bukan berarti membiarkan, tetapi mengikuti, memperhatikan, memotivasi, bahkan menjaga keselamatannya. Selama asuhannya beraktivitas normal, baik, benar, bagus, dan berguna; pengasuh hanya mengikuti dan memperhatikannya. Tetapi jika keadaan sebaliknya, maka pengasuh turun tangan untuk membantunya atau mencegah dari hal-hal yang akan membahayakan dirinya dan orang lain.

Berdasarkan pengalaman praktik, pihak yang diikuti, diperhatikan, dan dipengaruhi oleh pamong praja itu adalah pemerintah di tingkatan yang lebih bawahnya dan rakyat yang berada di wilayah kerjanya. Pemerintah mana yang dikatakan lebih bawahnya tergantung pada pengaturan undang-undang 
pemerintahan daerah yang berlaku pada tiap-tiap masanya. Misalnya, pemerintah di tingkatan yang lebih bawah dari provinsi adalah kabupaten/kota, tingkatan yang lebih bawah dari kabupaten/kota adalah kecamatan, dan tingkatan yang lebih bawah dari kecamatan adalah desa atau kelurahan.

Dalam struktur pemerintahan yang demikian, pamong praja berperan dalam perencanaan, pelaksanaan dan pengendalian, serta menggerakkan partisipasi masyarakat dalam pembangunan. Peranan pamong praja dalam pekerjaan ini terrasa banyak sekali. Misalnya dari pengalaman pribadi penulis sebagai camat, bagaimana camat mengkoordinasikan instansi tingkat kecamatan dan desa dalam mengatasi berbagai persoalan pembangunan di wilayah kerjanya.

Dalam kaitannya dengan kemasyarakatan, pengalaman praktik menunjukkan bahwa pamong praja sering diperankan sebagai "sesepuh" masyarakat. Pamong praja dianggap bagian dari tubuh masyarakat. Bahkan pamong praja yang sudah pensiunpun banyak yang masih diperankan hampir sama dengan yang masih aktif. Mereka dijadikan tempat bertanya, berkonsultasi, bahkan dimintai pertolongan atau pendapat berkenaan dengan kepentingannya masing-masing, terutama yang berkaitan dengan politik, pemerintahan, kemasyarakatan, dan pembangunan.

Berkenaan dengan kenegaraan, pamong praja telah menunjukkan peranannya sebagai "penguat ikatan negara kesatuan" di tiap-tiap daerah penugasannya dari sejak awal kemerdekaan RI sampai sekarang. Mereka telah menunjukkan bahwa pemerintah pusat hadir bersama-sama pemerintah bawahannya beserta instansi vertikal yang dikoordinasikannya untuk "menggalang persatuan dan kesatuan bangsa, memberikan pelayanan kepada masyarakat, dan menjaga ketenteraman dan ketertiban."

Pada masa awal kemerdekaan, dengan UU No.1 tahun 1945 ditetapkan bahwa pemerintahan di daerah diselenggarakan oleh Kepala Daerah bersama 
Komite Nasional Daerah. Sejak itu, pamong praja bersama bawahannya dan para pejuang lainnya berjuang untuk menegakkan kemerdekaan RI.

Pada masa selanjutnya, pamong praja memperjuangkan agar negara Indonesia tidak berbentuk federal, melainkan tetap berbentuk negara kesatuan. Karena itu, korp ini sangat menentang kehadiran UU No. 1/1957 yang berbau federalisme yang diupayakan Belanda karena ingin tetap menguasai Indonesia.

Itulah mungkin latar belakangnya mengapa The Liang Gie (1967: 173) berpendapat bahwa dalam rangka dekonsentrasi, pamong praja memiliki 3 peranan, yaitu :

1) sebagai instansi penengah (arbitrer) di antara kepentingan yang saling bertentangan dan bermusuhan;

2) sebagai instansi penghubung di antara lingkungan hukum tata negara yang berlainan; dan

3) sebagai pemelihara dan penegak ketenteraman dan keamanan umum yang dalam hal ini berhubungan erat dengan pihak kepolisian negara.

\section{Penutup}

Sebagai penutup, penulis menyimpulkan bahwa selama Republik Indonesia berbentuk negara kesatuan, selama itu pula pekerjaan dekonsentrasi dan pemerintahan umum tetap ada. Seluas apapun otonomi yang diberikan kepada Daerah, peranan pemerintah pusat dalam penyelenggaraan pemerintahan daerah akan tetap ada. Itu artinya, sekalipun sebutan pamong praja jarang dimunculkan, namun hakikat kedudukan, fungsi, dan peranannya tetap ada. 


\section{Daftar Pustaka}

Departemen Pendidikan dan Kebudayaan RI, 1996, Kamus Besar Bahasa Indonesia, edisi kedua, Jakarta: Balai Pustaka.

Gie, The Liang, 1968, Pertumbuhan Pemerintahan Daerah Di Indonesia Jilid I,Jakarta: Gunung Agung.

Kansil, C.C.T, 1981, Sistem Pemerintahan Indonesia, Jakarta: Aksara Baru.

Koesoemahatmadja, Djenal Hoesen, 1978, Fungsi \& Struktur Pamong Praja, Bandung: Alumni.

Koswara, E., 2000, Makna Otonomi Daerah Bagi Negara Kepulauan Seperti Indonesia Dan Prospeknya Dalam Abad 21, Artikel dalam Jurnal Ilmu Pemerintahan Edisi 10 tahun 2000, Jakarta: IPDN.

Roesmidi dkk, 2010, Pemerintahan Umum, Modul Perkuliahan Jatinangor: Institut Pemerintahan Dalam Negeri.

Sallata,B.L, 1983, Peningkatan Dan Pemantapan Tugas-Tugas Pamong Praja Dalam Rangka Pelaksanaan PP 27/1956, Jakarta: Yayasan Karya Dharma Institut Ilmu Pemerintahan.

Soejito, Irawan, 1981, Hubungan Pemerintah Pusat dan Pemerintah Daerah, Jakarta: Bina Aksara.

Soleh, Chobib, dan Bambang Trisantono, 2001, Pamong Praja Dalam Perspektif Sejarah, Depok: Citra Utama.

Sugandha, Dann, 1981, Masalah Otonomi Serta Hubungan Antara Pemerintah Pusat Dan Daerah Di Indonesia, Bandung: Sinar Baru

Suryaningrat, Bayu, 1980, Pamong Praja Dan Kepala Wilayah, Jakarta: Aksara Baru. 
Suryaningrat, Bayu, 1976, Wewenang, Tugas, Dan Kewajiban Camat, Jakarta: Yayasan Beringin KORPRI Unit Departemen Dalam Negeri.

Wasistiono, Sadu, dan Mansur, 2010, Desentralisasi dan Otonomi Daerah, Modul Perkuliaha, Jatinangor: Institut Pemerintahan Dalam Negeri. 